\title{
TOXICITY OF Jatropha curcas L. LATEX IN Allium cepa TEST
}

\section{TOXICIDADE DO LÁTEX DE Jatropha curcas L. NO MODELO DE Allium cepa}

\author{
Angelina Luzia CIAPPINA ${ }^{1}$; Fabrício Alves FERREIRA ${ }^{2}$; Illana Reis PEREIRA ${ }^{2}$; \\ Tiago Rodrigues SOUSA ${ }^{2}$; Fábio Santos MATOS ${ }^{3}$; Paulo Roberto MELO-REIS ${ }^{4}$; \\ Pablo José GONÇALVES ${ }^{5}$; Elisa Flávia Luiz Cardoso BAILÃO ${ }^{6}$; \\ Luciane Madureira ALMEIDA ${ }^{7}$
}

1. Agrônoma, Laboratório de Biologia Molecular de Plantas, Universidade Estadual de Goiás - UEG, Ipameri, GO, Brasil; 2. Mestre em Produção Vegetal, Laboratório de Biologia Molecular de Plantas - UEG, Ipameri, GO, Brasil; 3. Professor, Doutor, Laboratório de Fisiologia Vegetal -UEG, Ipameri, GO, Brasil; 4. Professor, Doutor, Departamento de Biomedicina, Laboratório de Estudos Experimentais e Biotecnológicos, Pontifícia Universidade Católica de Goiás -PUCGo. Goiânia, GO, Brasil; 5. Professor, Doutor, Laboratório de Fotofísica, Instituto de Física Federal de Goiás - UFG, Goiânia, GO, Brasil; 6. Professora, Doutora, Universidade Estadual de Goiás, Anápolis, GO Brasil; 7. Professora, Doutora, Universidade Estadual de Goiás, Anápolis, GO Brasil. almeidalm@hotmail.com

\begin{abstract}
The latex obtained from Jatropha curcas (physic nut) is used in traditional medicine to treat a variety of disturbs, including burns, hemorrhoids, ringworm and ulcers. Phytochemical analyses have shown that $J$. curcas latex contains natural compounds with therapeutic potential. In this study, the toxicity, cytotoxicity and genotoxicity effects of $J$. curcas latex on the root cells of Allium cepa were examined. Onion seeds and bulbs were exposed to seven different concentrations of latex and then the roots were submitted to macro and microscopic analyses. Water and sodium azide were used as negative and positive controls, respectively. The analysis of root growth showed that $J$. curcas crude latex or $50 \%$ diluted is highly toxic. Cytogenetic results showed that the mitotic index of the onion roots submitted to latex treatment decreased significantly compared to the negative control, which suggests that the latex is cytotoxic. High incidence of chromosome aberrations in the cells treated with J. curcas latex was observed too, indicating that the latex also presents genotoxic effect. The analyses presented in this report suggest the toxic, cytotoxic and genotoxic effects of $J$. curcas latex. Then, the indiscriminate use of $J$. curcas latex in folk medicine could bring risk to human health.
\end{abstract}

KEYWORDS: Antiproliferative effect. Genotoxicity. Medicinal plants and physic nut.

\section{INTRODUCTION}

Medicinal herbs have been used in folk medicine for a long time and they have played a promising role in the treatment and prevention of various human diseases (AL-ASMARI et al., 2014). Despite the therapeutic advantages of medicinal plants, their potential toxicity is not recognized by the general public or by many professional groups of traditional medicine (SOETAN; AIYELAAGBE, 2009). Many plant species commonly considered medicinal can contain potentially dangerous substances (RODRIGUES et al., 2011; MELOREIS et al., 2011). Recent research studies conducted in vitro and in vivo revealed that many plants used as food or in traditional medicine have cytotoxic and genotoxic effects (SEHGAL et al., 2006; DALLA NORA et al., 2010; CARDOSO et al., 2014). Cytotoxic and genotoxic studies have great importance in the establishment of standard quantities and extraction methods for safe and effective use of these plants by the population (ASARE et al., 2012).

Jatropha curcas, known as physic nut, is a multipurpose plant from the Euphorbiaceae family (DUTTA et al., 2007). People in almost all parts of the world have been using this plant against alopecia, ascites, burns, convulsions, cough, dermatitis, diarrhea, dropsy, dyspepsia, fever, syphilis, tumors, ulcers, yaws and others (DEBNATH; BISEN, 2008). The latex of this plant is particularly used in the treatment of burns, hemorrhoids, ringworm and ulcers (DEBNATH; BISEN, 2008). Besides the widespread use of $J$. curcas by the population, there is some information about the toxic potential of different parts of this plant (SANTOS et al., 2008). Poisoning with $J$. curcas seeds or fruits have been reported. Gastrointestinal disorders within the first hours following ingestion, such as nausea, vomiting, diarrhea and abdominal pain, were always presented. Neurological or cardiovascular signs, and hepatic or renal disorders were sometimes associated (LANGRAND et al., 2015).

Phytochemical analyses showed that $J$. curcas latex contains natural compounds with biological activities. Peptides present in J. curcas have been reported as cytotoxic, such as curcucyclins A and B (INSANU et al., 2012). Moreover, it has been isolated a protease from the $J$. curcas latex, known as curcain, that exhibit woundhealing property when tested on mice (NATH; 
DUTTA, 1991). J. curcas latex also contains alkaloids, including jatrophine and jatropham that have been demonstrated as anti-cancer (THOMAS et al., 2008). Despite the knowledge of the phytochemical composition, few studies have reported the toxic potential of $J$. curcas latex.

The Allium cepa assay has been widely used for evaluation of cytotoxic and genotoxic activity of various compounds (RIBEIRO et al., 2016; DEL CAMPO et al., 2005; BARBÉRIO et al., 2009; ROA et al., 2012; FRESCURA et al., 2013), including medicinal herbs (BAGATINI et al., 2007). It has been validated by an international collaborative study by the United Nations Environmental Program (UNEP), World Health Organization (WHO) and US Environmental Protection Agency (USEPA) as an efficient test for genetic monitoring (BADMUS et al., 2013). One of the parameters evaluated in this assay is the mitotic index (MI), characterized by the number of cells in division relative to the total number of analyzed cells. The MI is used as a parameter to assess the cytotoxicity of several agents. MIs significantly lower than the negative control can indicate alterations deriving from the chemical action on the growth and development of the exposed organism. On the other hand, MIs higher than the negative control indicate an increase in cell division, which can be harmful to the cells and lead to disorderly cell proliferation and even to the formation of tumor tissues (LEME; MARIN-MORALES, 2009). Other parameters analyzed in the $A$. cepa assay were the presence of chromosome aberrations and micronucleus formation, indicating genotoxic potential of the tested compound, and root appearance and length alterations, which could point to toxicity potential of the tested compound (LEME; MARIN-MORALES, 2009).

Therefore, the Allium cepa assay is an efficient bioindicator for the first screening of medicinal plant toxicity, cytotoxicity and genotoxicity for: 1) its kinetic proliferation properties; 2) having large chromosomes which are few in number $(2 \mathrm{n}=16)$; and 3$)$ its reliability and agreement with other toxicity tests (LACERDA et al., 2014; NEVES et al., 2014; ALMEIDA et al., 2014; FRESCURA et al., 2013; LEME; MARINMORALES, 2009). Thus, this assay has been aiding human health damage prevention studies (BAGATINI et al., 2007). So, the present study was undertaken to evaluate the toxic, cytotoxic and genotoxic potential of different concentrations of $J$. curcas latex on Allium cepa meristematic root cells.

\section{MATERIAL AND METHODS}

\section{Latex extraction}

The latex of $J$. curcas was extracted from Universidade Estadual de Goiás tree collection, in Ipameri (Goiás, Brazil). A voucher specimen (10.042) was deposited at the University Herbarium (Universidade Estadual de Goiás, Anápolis, Goiás, Brazil). The latex was collected into a sterile container through cuts made into the tree trunk. The cuts were made into the bark with a knife and had approximately $10 \mathrm{~cm}$ length and $0.5 \mathrm{~cm}$ depth.

\section{Germination test}

Allium cepa seeds of the commercial cultivar (Sementes Vidasul Ltda) were used in order to evaluate the toxic effects of J. curcas latex. The latex was mixed with ultrapure water and quickly applied on germination paper in gerbox. Seven concentration of the latex were tested for toxicity $(100 \%, 50 \%, 10 \%, 5 \%, 1 \%, 0.5 \%$ and $0.1 \%)$. The experiments were made in triplicate using 35 seed in each time. Ultrapure water was used as negative control solution.

Onion seeds were pre-soaked for $48 \mathrm{~h}$ in gerbox containing moistened germitest paper with distilled water and maintained at $21 \pm 1{ }^{\circ} \mathrm{C}$. After the seeds were transferred to gearboxes containing paper soaked in different extracts, except the negative control sample, which remained in water distilled. The count was performed six days after the experiment beginning and the germination test was performed. The seeds that presented radicle with at least $50 \%$ of the seed size were considered germinated (FERREIRA; L'AQUILA, 2000). The germinability $(\mathrm{G})$ was calculated using the following formula: $G=(N / A) \times 100$. Where $N$ is total number of germinated seeds; $\mathrm{A}$ is the total number of seeds placed to germinate. The length of radical was measure at 6 days after germination induction using scale.

\section{Allium cepa assay}

Onion bulbs were grown in water at room temperature for 2-3 days. When the roots were 2-4 $\mathrm{cm}$ in length, the bulbs were treated with different concentrations of $J$. curcas latex $(10 \%, 5 \%, 1 \%$, $0.5 \%$ and $0.1 \%$ ). Another set of plants was placed in sodium azide ( $2 \mathrm{M}$ ) as a positive control, while for negative control, a set of $A$. cepa remained in water. The solutions were changed daily, and after $48 \mathrm{~h}$ the root tips from each bulb were harvested and fixed in Carnoy's fixative solution (1:3 acetic acid: ethyl alcohol) for $24 \mathrm{~h}$. Then, they were prepared for microscopic analysis or stored in 70\% ethyl alcohol. 
Before the slide preparation the roots were rinsed a few times with distilled water. After, they were hydrolyzed with $5 \mathrm{M} \mathrm{HCl}$ solution at room temperature for $20 \mathrm{~min}$. After hydrolysis, the roots were dissected in acetic acid (45\%) and squashed with cover slip. The cover slips were removed after freezing in liquid nitrogen and stained with Giemsa (5\%) for 5-10 $\mathrm{min}$.

The slides were evaluated using a LEICA ${ }^{\circledR}$ Optical Microscope with magnification of 40 or 100 x. In total, 1,000 cells were analyzed per bulb, in 5 bulbs per treatment. The cytotoxic potential was calculated through observation of the mitotic index (MI). The MI was calculated for each treatment, by comparing the number of dividing cells with the total number of cells (SETH et al., 2008). The genotoxic potential was estimated by the frequency of anomalies in the mitotic cycle (AMC).

For the statistical analysis the groups were divided into five treatments, each containing five replications, and the values were measured through variance analysis (ANOVA) and compared through Tukey test (SISVAR, 2010). The value $\mathrm{p}<0.05$ was considered as indicative of significance.
CIAPPINA, A. L. et al.

\section{RESULTS}

The inhibitory effect of $J$. curcas latex on the germination and growth of A. cepa root meristems was evaluated and compared with the positive control (Table 1). The germinability rate was calculated and showed that the $J$. curcas crude latex or $50 \%$ diluted decrease and almost prevented seed germination. On the other hand, the others latex solution concentrations $(10 \%, 5 \%, 1 \%, 0.5 \%$ and $0.1 \%$ ) do not seem to interfere in the germination process, once the germination frequency was similar to the water. In relation to the radicule length, a progressive increase in root during the 6 days of incubation was observed in the seeds exposed to water and diluted latex solutions (10\%, $5 \%, 1 \%, 0.5 \%$ and $0.1 \%$ ). On the other hand, high latex concentrations (100 and 50\%) cause a significant decrease in root length. This result indicates that $J$. curcas in high concentration are toxic to onion seeds, decreasing the germination rate and root length.

Table1. Germination rate (GR) and root length in Allium cepa seeds after J. curcas latex exposure.

\begin{tabular}{ccc}
\hline Treatment & $\begin{array}{c}\text { Germination Rate } \\
(\%)\end{array}$ & $\begin{array}{c}\text { Root Length } \\
\text { Mean } \pm \text { SD }\end{array}$ \\
\hline Control (water) & 72,85 & $21.9 \pm 14.5 \mathrm{a}$ \\
$0.1 \%$ & 64,3 & $28.3 \pm 12.7 \mathrm{~b}$ \\
$0.5 \%$ & 75,7 & $29.2 \pm 13.5 \mathrm{~b}$ \\
$1 \%$ & 74,28 & $27,4 \pm 16.3 \mathrm{~b}$ \\
$5 \%$ & 78,57 & $23.4 \pm 14.4 \mathrm{a}$ \\
$10 \%$ & 70 & $22.7 \pm 12,0 \mathrm{a}$ \\
$50 \%$ & $34,2^{+}$ & $5.3 \pm 5.1 \mathrm{c}^{*}$ \\
$100 \%$ & $5^{+}$ & $4.3 \pm 1.5 \mathrm{c}^{*}$ \\
\hline
\end{tabular}

$* \mathrm{p}<0.05$; Same letters represent no significant difference using Tukey test; + Reduction of $50 \%$ in relation to the control.

Besides the seed germination, we used the onion bulbs exposed to J. curcas latex to evaluate the cytotoxic and genotoxic potential of the physic nut latex. The mitotic index (MI) was taken into consideration to evaluate cytotoxicity, and chromosome aberrations (CA) was recorded to evaluate genotoxicity. The results obtained showed that all three latex concentrations of $J$. curcas significantly inhibited the MI of A. cepa meristematic root cells (Table 2), and does not differ significantly from positive control. In addition, the MI decreased progressively as the latex concentration increased (Table 2), showing that latex concentration is negatively correlated with MI. To be considered cytotoxic, a substance should cause MI reduction greater than 50\%, when compared with the control substance (GREENWOOD et al., 2004). The results obtained for $J$. curcas latex in the present work were higher than $50 \%$ in all concentrations, which suggested that $J$. curcas latex is cytotoxic even at very low concentrations.

To evaluate the genotoxic potential it was observed the chromosome aberrations frequency. The results showed that chromosome aberrations were observed in low incidence at $1 \%$ and $0.5 \%$ latex concentrations. However the number of aberrations increased drastically when the latex was diluted to $0.1 \%$ (Table 2). One possible explanation for these results is that at high latex concentrations, the MI is very low and it is not possible to observe cells in division. But when the MI increased with 
latex dilution ( $0.1 \%$ group), it was possible to observe cells in division. Among the cells dividing in the bulbs exposed to $0.1 \%$ latex, it was possible to identify high occurrence of chromosome aberrations. Among the different types of abnormalities observed, the most common were: chromosome stickiness, chromosome bridging and lagging chromosomes (Figure 1).

Table 2. Cytogenetic analysis of A. cepa roots exposed to different concentrations of $J$. curcas latex.

\begin{tabular}{|c|c|c|c|c|c|}
\hline \multirow[b]{2}{*}{ Treatments } & \multirow[b]{2}{*}{$\begin{array}{c}\text { Total } \\
\text { number } \\
\text { of cells }\end{array}$} & \multirow[b]{2}{*}{$\begin{array}{l}\text { Interphase } \\
\text { cells }\end{array}$} & \multirow[b]{2}{*}{$\begin{array}{l}\text { Division } \\
\text { cells }\end{array}$} & Cytotoxicity & \multirow{2}{*}{$\begin{array}{c}\text { Genotoxicity } \\
\text { Chromosome } \\
\text { aberrations } \\
\text { (CA \%) }\end{array}$} \\
\hline & & & & $\begin{array}{c}\text { Mitotic index (MI } \\
\%)\end{array}$ & \\
\hline Latex $1 \%$ & 5000 & 4500 & 50 & $1.0 \mathrm{~A}$ & $3 a$ \\
\hline Latex $0.5 \%$ & 5000 & 4921 & 79 & $1.6 \mathrm{~A}$ & $23 \mathrm{a}$ \\
\hline Latex $0.1 \%$ & 5000 & 4643 & 357 & $7.1 \mathrm{~A}$ & $253 b^{*}$ \\
\hline Water & 5000 & 3705 & 1295 & $26 \mathrm{~B} *$ & $0 \mathrm{a}$ \\
\hline Sodium azide & 5000 & 4579 & 421 & $8.4 \mathrm{~A}$ & $254 b^{*}$ \\
\hline
\end{tabular}

$* \mathrm{p}<0.05$; Same letters represent no significant difference using Tukey test.

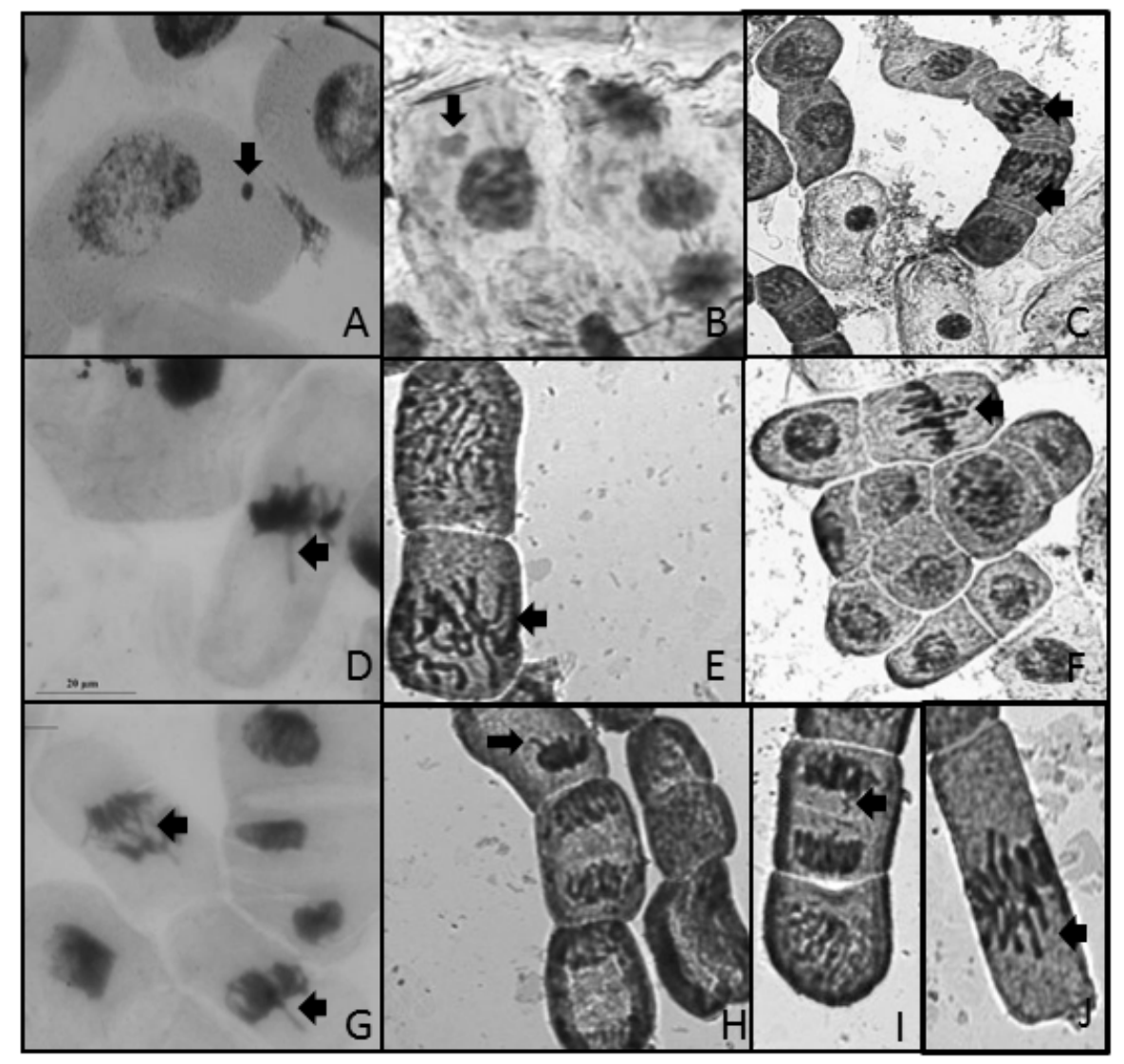

Figure 1. Mitotic and chromosomal aberrations after the $J$. curcas latex treatments in Allium cepa root tip meristem cells visualized with light microscopy. A and $\mathbf{B}$ : interphase cells with micronucleus; $\mathbf{C}$ : chromosome stickiness and lagging; D: chromosome lagging; E: chromosome stickiness; F: chromosome break; G. chromosome bridges; H and I: chromosome lagging; J. chromosome stickiness. Arrows indicated the abnormalities. 


\section{DISCUSSION}

Although an expressive number of medicinal plant species are known and used in popular medicine, detailed studies of the pharmacological and biological activity of many of them remain elusive. In the case of $J$. curcas, different parts of this plant, such as roots, bark latex, leaves, seeds and oil, have been employed empirically in popular medicine (THOMAS et al., 2008). However, detailed evaluation of their effectiveness, pharmacological and toxic potential, molecular action, or proper dosage remains elusive.

In the present study, the A. cepa test system was used to evaluate the toxic (seed germination rate and root growth), cytotoxic (mitotic index frequency) and genotoxic (chromosome abnormality) effects of different concentrations of $J$. curcas latex. Regarding toxicity, the results obtained showed retarded growth of all the roots submitted to the latex treatment. Crude latex and diluted 50\% with water suggesting that $J$. curcas latex are highly toxic. Also, it was possible to infer that toxicity was dose-dependent, since higher latex concentrations showed the highest toxic effects. On the other hand, latex diluted solutions stimulate the root growth comparing with water treatment. In that way, the root growth was dose-dependent and the smallest latex concentration showed the highest root growth.

In addition to medicinal use, $J$. curcas has been considered to be one of the most promising oilseeds for biofuel production (DEVAPPA et al., 2012). In this way, the seeds have been the main economic use of this species. Considering the economic potential of this part of J. curcas, some authors have evaluated the toxic potential of the oilseeds using different bioassays. Andrade-Viera (2014) showed the phyto, cyto and genotoxic effects of oil extracted from $J$. curcas seeds in Lactuca sativa, and suggested that this assay can be used to identify toxic and nontoxic varieties of physic nut. Devappa et al. (2012) showed that phorbol esters from $J$. curcas seeds exert a toxic effect on snail, brine, shrimp and daphinia bioassays, and also in microorganisms. Rakshit et al. (2008) tested $J$. curcas oil toxicity in rats and observed that all rats showed reduced appetite and low diet intake, accompanied by diarrhea. All authors have been attributed the toxicity of natural compounds present in $J$. curcas to the phorbol esters. The phorbol esters are diterpenes having tigliane skeleton. In J. curcas, six types of phorbol esters have been reported (HAAS et al., 2002).

In specific regard to $J$. curcas latex cytotoxicity, there are few reports indicating cytotoxic activity of the crude extract. Ribeiro et al. (2012) tested the leaves cytotoxicity in human tumor cell lines using the thiazolyl blue test (MTT) assay and observed significant cell mortality. Despite the high mortality, the mechanism responsible for the cytotoxic activity has not been investigated yet. The authors suggest that the cytotoxicity could be associated with the presence of substances curcin, curcusone (A, B, C and D), ultidione, jatropholone and acetoxyjatropholone in the $J$. curcas species.

On the other hand, the toxic effect of these isolated compounds has been intensely evaluated. For example, there are different reports showing the toxic activity of curcin (LIN et al., 2003; QIN et al., 2010; HE et al., 2011; PRAHAN et al., 2012; ZAHO et al., 2012; JARAMILLO-QUINTERO et al., 2015). Curcin is a toxalbumin protein extracted from $J$. curcas seeds that present in vitro effect inhibiting protein synthesis, which is called ribosome-inactivating protein (RIP). Curcin has shown antitumor effect on different tumors cells (gastric cancer cell line; mouse myeloma cell line; carcinoma cell line), and its mechanism is related to $\mathrm{N}$-glycosidase activity (LIN et al., 2003). The curcusones are other important compounds extracted from $J$. curcas latex. They are diterpenes with strong inhibitory and cytotoxic activity (AIYELAAGBE et al., 2011). Four curcusones have been identified in this species (curcusones A, B, C and $\mathrm{D}$ ), and all of them showed anticancer activity. Curcusone $\mathrm{B}$, in particular, effectively suppresses the metastatic processes at doses that are non-toxic to cells, which may be of therapeutic benefit for the treatment of metastatic cancers (MUANGMAN et al., 2005). Another diterpene found in the latex is the jatropholone, which also presented antiproliferative activity in human cell culture (THEODULOZ et al., 2009). J. curcas latex also contains cyclic peptides, such as octapeptides (curcacycline A and jatrophidin) and cyclic nonapeptides (curcacycline B), that could possess cytotoxic, antimalarial and antimicrobial activity (SABANDAR et al. 2013).

In relation to the genotoxic activity of the latex, to the best of our knowledge to date there are no reports evaluating the genotoxic effect of $J$. curcas latex. Our results showed that at $1 \%$ and $0.5 \%$ the latex did not present detectable genotoxic effect when compared with the negative control (water). However, at the lowest concentration $(0.01 \%)$ the latex showed highly genotoxic activity. In fact, the genotoxic effect is not observed in cells submitted to higher concentrations of latex because the latex inhibits cell division (MI), and it is not 
possible to visualize the chromosomes in the $A$. cepa assay. At lowest latex concentration it was possible to observe chromosome aberrations, such as chromosome stickiness, chromosome bridges and lagging chromosomes. The sticky chromosome represents changes in the chromosomal structure and can be associated with the action of toxic compounds on DNA and/or protein structure. The sticky chromosome change is usually irreversible and generally leads to cell death (EL-GHAMERY et al., 2003). A chromosome bridge rises when the chromosome fails to separate due to chromosome stickiness (YADAV, 1986). Sticky chromosomes and chromosome bridges are abnormalities that characterize the aneugenic action of the components of the J. curcas latex. The genotoxic potential of Jatropha gossypiifolia latex was also investigated. Similarly to what was observed to $J$. curcas latex, $J$. gossypiifolia latex showed a significant decrease in root growth and in the mitotic index for the tested concentrations $(0.1 \%, 0.2 \%, 0.5 \%, 1 \%$ and $2 \%)$. The $0.1 \%, 0.2 \%, 0.5 \%$ concentrations induced significant chromosome adherences, C-metaphases and/or chromosome bridges, suggesting genotoxic effects (ALMEIDA et al., 2015).
CIAPPINA, A. L. et al.

The present study demonstrated that the latex extracted from $J$. curcas has natural compounds that exert toxic, cytotoxic and genotoxic effects on Allium cepa roots. The knowledge of the latex effect on cells is still preliminary, requiring more studies to determine the mechanisms of action of the latex natural compounds and the suitable dosage for safe and effective use by the population. Studies involving the genotoxicity of medicinal plants are important, because they can alert the population about possible and eventual damages to health (TEDESCO et al., 2015). Our results showed that the empirical utilization of $J$. curcas latex in popular medicine could be harmful to human health and should be avoided.

\section{ACKNOWLEDGEMENTS}

We would like to thank the financial support provided by FAPEG/CAPES (AUXPE 2370/2014 and AUXPE 011/2012). The authors also wish to thanks the financial support provided by MCT/CNPq, FNDCT, CAPES, FINEP and FAPEG (Centro-Oeste project) and Goiás State University (UEG) by granting of incentive to research (BIP).

RESUMO: O látex obtido de Jatropha curcas (pinhão manso) é usado na medicina tradicional para tratamento de diversos distúrbios, como queimaduras, hemorroida, micose e úlcera. Análises fitoquímicas apontaram que o látex de $J$. curcas contém compostos naturais com potencial terapêutico. Este estudo avaliou a toxicidade, citotoxicidade e genotoxicidade do látex de J. curcas em células da raiz de Allium cepa. Sementes e bulbos de cebola foram expostos á sete diferentes concentrações de látex e, então, as raízes foram submetidas a análises macro e microscópica. Água e azida sódica foram utilizadas como controle negativo e positivo, respectivamente. A análise do comprimento das raízes mostrou que o látex de $J$. curcas puro e diluído a $50 \%$ é altamente tóxico. O índice mitótico das raízes de cebola submetidas ao tratamento com o látex diminuiu significativamente comparado com o controle negativo, o que sugere que o látex é citotóxico. Uma alta incidência de aberrações cromossômicas em células tratadas com o látex de $J$. curcas também foi observada, indicando que o látex apresenta efeito genotóxico. Essa análise sugere que o látex de $J$. curcas possui efeitos tóxico, citotóxico e genotóxico, sendo que o uso indiscriminado do látex de $J$. curcas na medicina popular pode trazer risco à saúde humana.

PALAVRAS-CHAVE: Efeito antiproliferativo. Genotoxicidade. Plantas medicinais e pinhão manso.

\section{REFERENCES}

AIYELAAGBE, O. O.; HAMID, A. A.; FATTORUSSO, E.; TAGLIALATELA-SCAFATI, O.; SCHRÖDER, H. C.; MULLER, W. E. G. Cytotoxic activity of crude extracts as well as of pure components from Jatropha species, plants used extensively in African traditional medicine.Evidence-Based Complementary and Alternative Medicine, 2011. https://doi.org/10.1155/2011/134954

AL-ASMARI, A.; AL-ELAIWI, A. M.; ATHAR, M . D. T.; TARIQ, M.; AL-EID, A.; AL-ASMARY, S. M. A review of Hepatoprotective plnats used in Saudi traditional medicine. Evidence-Based Complementary and Alternative Medicine, 2014. https://doi.org/10.1155/2014/890842 
ALMEIDA, L. M.; FLORIANO, J. F.; RIBEIRO, T. P.; MAGNO, L. N.; MOTA, L. S. L. S.; PEIXOTO, N.; MRUÉ, F. N. P.; MELO-REIS, P.; LINO, R. S. J.; GRAEFF, C. F. O.; GONÇALVES, P. J. Hancornia speciosa latex for biomedical applications: physical and chemical properties, biocompatibility assessment and angiogenic activity. Journal of Materials Science. Materials in Medicine, New York, v. 55, n. 9, p. 1-8, 2014.

ALMEIDA, P. M.; SOUSA ARAÚJO, S.; MARIN-MORALES, M. A.; BENKO-ISEPPON, A. M.; BRASILEIRO-VIDAL, A. C. Genotoxic potential of the latex from cotton-leaf physicnut (Jatropha gossypiifolia L.). Genet Mol Biol, v. 38, n. 1, p. 93-100, 2015. https://doi.org/10.1590/S1415475738120140162

ANDRADE-VIEIRA, L. F.; BOTELHO, C. M.; LAVIOLA, B. G.; PALMIERI, M. J.; PRAÇA-FONTES, M. M. Effects of Jatropha curcas oil in Lactuca sativa root tip bioassays. Annals of the Brazilian Academy of Sciences, Rio de Janeiro, v. 86, n. 1, p. 373-382,2014.

ASARE, G. A.; BUGYEI, K.; SITTIE, A.; YAHAYA, E. S.; GYAN, B.; ADJEI, S.; ADDO, P.; WIREDU, E. K.; ADJEI, D. N.; NYARKO, A. Genotoxicity, cytotoxicity and toxicological evaluation of whole plant extracts of the medicinal plant Phyllanthus niruri(Phyllathaceae). Genetics Molecular Research, Ribeirão Preto, v. 11, n. 1, p. 100-111, 2012. https://doi.org/10.4238/2012.January.13.3

BADMUS, J. A.; ODUMOLA, A. O.; YEKEEN, T. A.; GBADEGESIN, A. M.; FATOKI, J.O.; GODO, M. O.; OYEBANJO, K. S.; HISS, D. Evaluation of antioxidant, antimutagenic and lipid peroxidation inhibitory activities of selected fractions of Holarrhena floribunda (G Don) leaves.Acta Biochimica Polonica, Kraków, v. 60 , n. 3, p. 435-442, 2013.

BAGATINI, M. D.; SILVA, A. C. F.; TEDESCO, S. B. Uso de sistema-teste Allium cepa como bioindicador de genotoxicidade de infusões de plantas medicinais. Brazilian Journal of Pharmacognosy, Curitiba, v. 18, n. 3, p. 509-516, 2007. https://doi.org/10.1590/s0102-695x2007000300019

BARBÉRIO, A.; BARROS, L.; VOLTOLINI, J. C.; MELLO, M. L. S. Evaluation of the cytotoxic and gentotoxic potential of water from river Paraiba do Sul in Brazil with Allium cepa test. Brazilian Journal Biology, São Carlos, v. 69, n. 3, p. 837-842, 2009. https://doi.org/10.1590/S1519-69842009000400010

CARDOSO, G. H. S.; DANTAS, E. B. S.; SOUSA, F. R. C.; PERON, A. P. Cytotoxicity aqueous extracts of Rosmarinus officinalis L (Labitae) in plant test system. Brazilian Journal Biology, São Carlos, v. 74, n. 4, p. 886-889, 2014. https://doi.org/10.1590/1519-6984.07313

DALLA-NORA, G.; PASTORI, T.; LAUGHIGHOUSE, H. D.; CANTO-DOROW, S. T.; TEDESCO, S. B. Antiproliferative and genotoxic effects of Mikania glomerata (Asteraceae). Biocell, Mendonza, v. 34, n. 3, p. 95-101, 2010.

DEBNATH, M.; BISEN, P. S.Jatropha curcas L, a multipurpose stress resistant plant with a potential for ethnomedicine and renewable energy. Current Pharmaceutical Biotechnology, Hilversum, v. 9, n. 4, p. 288306, 2008. https://doi.org/10.2174/138920108785161541

DEL CAMPO, A.; BRACHO, M.; MARCANO, L.; GUINEZ, J.; TORRE, C. DNA injury induced by 5aminouracil and caffeine in G2 checkpoints path of higher plant cells. Biocell, Mendonza, v. 29, n. 2, p. 169176, 2005.

DEVAPPA, R. K.; RAJESH, S. K.; KUMAR, V.; MAKKAR, H. P. S.;BECKER, K. Activities of Jathropha curcas phorbol esters in various bioassays. Ecotoxicology and Environmental Safety, New York, v. 78, n. 1, p. 57-62, 2012. https://doi.org/10.1016/j.ecoenv.2011.11.002

DUTTA, M. M.; MUKHERJEE, P.; GHOSH, B.; JHA, T. B. In vitro clonal propagation of biodiesel plant. Current Science, India, v. 93, n. 10, p. 1438-1442, 2007. 
EL-GHAMERY, A. A.; EL-KHOLY, M. A.;ABOU EL-YOUSSER, M. A. Evaluation of cytological effecs of $\mathrm{Zn}^{2+}$ in relation to germination and growth of Nigella sativa $\mathrm{L}$ and Truticum aestivum L. Mutation Research, Amsterdam, v. 537, n. 1, p. 29-41, 2003. https://doi.org/10.1016/S1383-5718(03)00052-4

FERREIRA, A. G.; AQUILA, M. E. A. Alelopatia: Uma área emergente da ecofisiologia. Revista Brasileira de Fisiologia Vegetal, São Paulo, v. 12, p. 175-204, 2000. Suplemento

FRESCURA, V. D. S.;KHUN, A. W.; LAUGHIGHOUSE, I. V.; PARANHOS, J. T.; TEDESCO, S. B. Posttreatment with plant extracts used in Brazilian folk medicine caused a partial reversal of the antiproliferative effect of glyohosate in the Allium cepa. Biocell, Mendonza, v. 37, n. 2, p. 23-28, 2013.

GREENWOOD, S. K.; HILL, R. B.; SUN, J. T.; ARMSTRONG, M. J.; JOHSON, T. E.; GARA, J. P.; GALLOWAY, S. M. Population doubling: a simple and more accurate estimation of cell growth suppression in the in vitro assay for chromosomal aberrations that reduces irrelevant positive results. Environmental and Molecular Mutagenesis, New York, v. 43, n. 1, p. 36-44, 2004. https://doi.org/10.1002/em.10207

HASS, W.; HEINZ STERK, H.; MITTELBACH, M. Novel 12-deoxy-16-hydroxyphorbol diesters isolated from the seed of Jatropha curcas. Journal of Natural Products, Washington, v. 65, n. 10, p. 1434-1440, 2002. https://doi.org/10.1021/np020060d

HE, W.; KING, A. J.; KHAN, M. A.; CUEVAS, J. A.; RAMIARAMANANA, D.; GRAHAM, I. A. Analysis of seed phorbol-ester and curcin content together with genetic diversity in multiple provenances of Jatropha curcas L from Madagascar and Mexico. Plant Physiology Biochemistry, India, v. 49, n. 10, p. 1183-1190, 2011. https://doi.org/10.1016/j.plaphy.2011.07.006

INSANU, M.; ANGGADIREDJA, J.; KAYSER, O. Curcacycline A and B - New pharmacological insights to an old drug. International Journal of Applied Research in Natural Products, Texas,v. 5, n. 2, p. 26-34, 2012.

JARAMILLO-QUINTERO, L. P.; CONTIS MONTES, OCA. A.; ROMERO ROJAS, A.; ROJASHERNÁNDEZ, S.; CAMPOS-RODRÍGUEZ, R.; MARTÍNEZ-AYALA, A. L. Cytotoxic effect of the immunotoxin constructed of the ribosome-inactivating protein curcin and the monoclonal antibody against Her2 receptor on tumor cells. Bioscience Biotechnology Biochemistry, Tokyo, v. 79, n. 6, p. 1-11, 2015.

LACERDA, L. P.; MALAQUIAS, G.; PERON, A. P. Antiproliferative action of aqueous extracts of Hymenaea stigonocarpa Mart (Fabaceae) on the cell cycle of Allium cepa L. Annals of the Brazilian Academy of Sciences, Rio de Janeiro, v. 86, n. 3, p. 1147-1150, 2014.

LANGRAND, J.; MÉDERNACH, C.; SCHMITT, C.; BLANC-BRISSET, I.; VILLA, A. F.; HARO, L.; GARNIER, R. Poisoning with Jatropha curcas: 24 cases reported to Paris and Marseille Poisons Centers. Bulletin de la Société de pathologie exotique, v. 108, n. 2, p. 139-143, 2015. https://doi.org/10.1007/s13149014-0412-3

LEME, D. M.; MARIN-MORALES, M. A. Allium cepa test in enverionmental monitoring: A review on its application. Mutation Research, Amsterdam, v. 682, n. 1, p. 71-81, 2009.

https://doi.org/10.1016/j.mrrev.2009.06.002

LIN, J.; YAN, F.; TANG, L.; CHEN, F. Antitumor effects of curcin from seeds of Jatropha curcas. Acta Pharmacologica Sinica, Shanghai, v. 24, n. 3, p. 241-246, 2003.

MELO-REIS, P. R.; BEZERRA, L. S. A.; VALE, M. A. A. B.; CANHÊTE, R. F. R.; CHEN-CHEN, L. Assessment of the mutagenic and antimutagenic activity of synadenium umbellatum Pax latex by micronucleus test in mice. Bazilian Journal Biology, São Carlos, v. 71, n. 1, p. 169-174, 2011. https://doi.org/10.1590/s1519-69842011000100024 
MUANGMAN, S.; THIPPORNWONG, M.; TOHTONG, R. Antimetastatic effects of curcusone B, a diterpene from Jatropha curcas. In Vivo, Athens, v. 19, n. 1, p. 265-268, 2005.

NATH, L. K.; DUTTA, K. S. Wound healing response of the proteolytic enzyme curcain. Indian Journal of Pharmacology, India, v. 24, n. 2, p. 111-115, 1992.

NEVES, E. S. B.; FERREIRA, P. M.; LIMA, L. H.; PERON, A. P. Action of aqueous extracts of Phyllantha niruri $L$ (Euphorbiaceae) leaves on meristematic root cells of Allium cepa. Annals of the Brazilian Academy of Sciences, Rio de Janeiro, v. 86, n. 3, p. 1131-1136, 2014.

PRADHAN, S.; NAIK, S. N.; KHAN, M. A.; SAHOO, P. K. Experimental assessment of toxic phytochemicals in Jatropha curcas: oil, cake, bio-diesel and glycerol. Journal of the Science of Food and Agriculture, Oxford, v. 92, n. 3, p. 511-519, 2012. https://doi.org/10.1002/jsfa.4599

QIN, X.; SHAO, C.; HOU, P.;GAO, J.; LEI, N.; JIANG, L.; YE, S.; GOU, C.; LUO, S.; ZHENG, X.; GU, X.; ZHU, X.; XU, Y.; CHEN, F. Different functions and expression profiles of curcin-L in Jatropha curcas L. A Journal of Biosciences, Tubingen, v. 65, n. 6, p. 355-362, 2010

RAKSHIT, K. D.; DARUKESHWARA, J.; RATHINA, R. A. J. K.; NARASIMHAMURTH, Y. K.; SAIBABA, P.; BHAGYA, S. Toxicity studies of detoxified Jatropha meal (Jatropha curcas) in rats. Food Chemical Toxicology, Oxford, v. 46, n. 12, p. 3621-3625, 2008. https://doi.org/10.1016/j.fct.2008.09.010

RIBEIRO, S. S.; JESUS, A. M.; ANJOS, C. S.; SILVA, T. B.; SANTOS, A. D. C.;JESUS, J. R.; ANDRADE, M. S.; SAMPAIO, T. S.; GOMES, W. F.; ALVES, P. B.; CARVALHO, A. A.; PESSOA, C.; MORAES, M. O.; PINHEIRO, M. L. B.; PRATA, A. P. N.; BLANK, A. F.; SILVA-MANN, R.; MORAES, V. R. S.; COSTA, E. V.; NOGUEIRA, P. C. L.; BEZERRA, D. P. Evaluation of the cytotoxic activity of some Brazilian medicinal plants. Revista Brasileira dePlantas Medicinais, Paulinia, v. 78, n. 14, p. 1601-1606, 2012. https://doi.org/10.1590/1519-6984.20114

RIBEIRO, T. P.; SOUSA, T. R.; ARRUDA, A. S.; PEIXOTO, N.; GONCALVES, P. J.; ALMEIDA, L. M . Evaluation of cytotoxicity and genotoxicity of Hancornia speciosa latex in Allium cepa root model. Brazilian Journal of Biology, São Carlos, v. 76, p. 245-249, 2016.

ROA, O.; YEBER, M. C; VENEGAS, W. Genotoxicity and toxicity evaluations of ECF cellulose bleaching effluents using Allium cepa test. Brazilian Journal Biology, São Carlos, v. 72, n. 3, p. 471-477, 2012. https://doi.org/10.1590/S1519-69842012000300009

RODRIGUES, H. G.; MEIRELES, C. G.; LIMA, J. T. S.; TOLEDO, G. P.; CARDOSO, J. L.; GOMES, S. L. Efeito embriotóxico, teratogênico e abortivo de plantas medicinais. Revista Brasileira de Plantas Medicinais, Botucatu, v. 13, n. 3, p. 359-366, 2011.

SABANDAR, C. W.; AHMAT, N.; JAAFAR, F. M.; SAHIDIN, I. Medicinal property, phytochemistry and pharmacology of several Jatropha species (Euphorbiaceae): A review. Phytochemistry, New York, v. 85, p. 729, 2013. https://doi.org/10.1016/j.phytochem.2012.10.009

SANTOS, W. L. C.; FRANÇA, F. A.; LOPEZ, L. B.; SILVA,G. M. S.; AVELAR, K. E. S.; MORAES, S. R. Atividades farmacológicas e toxicológicas da Jatropha curcas (pinhão-manso). Revista Brasileira de Farmácia, v. 89, n. 4, p. 333-336. 2008.

SEHGAL, R.; ROY, S.; KUMAR, V. L. Evaluation of cytotoxic potential of latex of Calotropis procera and Podophyllotoxin in Allium cepa. Biocell, Mendonza, v. 30, n. 1, p. 9-13, 2006.

SETH, C. S.; MISRA, V.; CHAUHAN, L. K. S.; SINGH, R. R. Genotoxicity of cadmium on root meristem cells of Allium cepa: cytogenetic and Comet assay approach. Ecotoxicology Environmental Safety, New York, v. 71, n. 3, p. 711-716, 2008. https://doi.org/10.1016/j.ecoenv.2008.02.003 
SISVAR - Sistema de análise de variância. Versão 5.3. Lavras-MG: UFLA, 2010.

SOETAN, K. O.; AIYELAAGBE, O. O. The need for bioactivity-safety evaluation and conservation of medicinal plants. A review. Journal of Medicinal Plants Research, Nairobi, v. 3, n. 5, p. 324-328, 2009.

TEDESCO, M.; KUHN, A. W; BOLIGON, A. A.; LAUGHINGHOUSE, H. D.; ATHAYDE, M. L.; SILVA, A. C. F.; TEDESCO, S. B. Chromatographic analysis, antiproliferative effect and genotoxicity of aqueous extracts of Citrus sinensis (1.) osbeck on the Allium cepa L. test system. Bioscience Journal, Uberlândia, v. 31, n. 4, p. 1213-1221, 2015. https://doi.org/10.14393/BJ-v31n4a2015-23245

THEODULOZ, C.; RODRÍGUEZ, J. A.; PERTINO, M.; SCHMEDA-HIRSCHMANN, G. 2009. Antiproliferative activity of the diterpenes jathrophone and jatropholone and their derivates. Revista Brasileira de Plantas Medicinais, Paulinia, v. 75, n. 14, p. 1520-1522, 2009.

THOMAS, R.; SAH, N.; SHARMA, P. 2008. Therapeutic Biology of Jatropha curcas: a mini review.Current Pharmaceutical Biotechnology, Hilversum, v. 9, n. 4, p. 315-324, 2008.

https://doi.org/10.2174/138920108785161505

YADAV, S. K. Antimitotic and cytological activities of Tropical Forest Tree: Tamarindus indica. Journal of Tropical Forestry, Kepong, v. 2, n. 1, p. 53-58, 1986.

ZHAO, Q.; WANG, W.; WANG, Y.; XU, Y.; CHEN, F. The effect of curcin from Jatropha curcas on apoptosis of mouse sarcoma-180 cells. Fitoterapia, Milano, v. 83, n. 5, p. 849-852, 2012.

https://doi.org/10.1016/j.fitote.2012.03.005 